\title{
ECOLOGY OF REGULATED STREAMS IN SPAIN: AN OVERVIEW
}

\author{
D. García de Jalón ${ }^{1}$, M. González del Tánago ${ }^{1}$ and C. Casado ${ }^{2}$ \\ 1. E.T.S. Ingenieros de Montes,Universidad Politécnica de Madrid. Spain. \\ 2. Lab. Limnologia. Dpto. Ecologia, Universidad Autónoma de Madrid. 28049 Madrid. Spain.
}

Keywords: Stream regulation, Limnology, Spain.

\begin{abstract}
A brief review of the main studies on flow regulation effects in Spain is presented, considering algae, fish and macroinvertebrate communities.

The eel (Anguilla anguilla), salmon (Salmo salar) and seatrout (Salmo trutta tr-utta) are perhaps the most affected species, having reduced their distribution area considerably. The response of macroinvertebrate communities to flow regulation changes from one river to another, due to the multiple use of reservoirs. A decrease of species richness and diversity have been frequently reported, being flow fluctuation and lower water temperature the main factors responsible for that.
\end{abstract}

\section{INTRODUCTION}

Nowadays all Spanish large rivers have their flows regulated by reservoirs, and most of the median size streams are also regulated. This intensive flow regulation tends to ameliorate an irregular distribution of the water resources, both in terms of space and time.

The space irregularity is explained because of climatic conditions, following a gradient from the more rainy areas in the Northwest (Atlantic influence) to the drier zones in the Southeast (Mediterranean influence), having a mean annual effective rainfall of $215 \mathrm{~mm}$. for the country.

The time irregularity is a consequence of the dominant mediterranean conditions, with intensive to very intensive precipitations during fall to early spring and a marked summer drought, having a large irregularity between years also.

Flow regulation has been one of the priorities in Spain during the 50's, and nowadays there are more than a thousand big dams constructed, taking advantage of the Iberian high relief. This amount of big reservoirs is completed with some water transfers, to reduce water differences between regions.

\section{RESERVOIRS}

The thousand of large reservoirs represents an storage capacity of near 45,000 million cubic'metres (DIRECCION
GENERAL OBRAS HIDRAULICAS, 1986), having most of them a multiple use. Hydropower generation is the most commun, using the $84 \%$ of this capacity, followed by irrigation that employes the $59 \%$ and the industrial and urban supply that represents a $26 \%$ of it.

Hydroelectric energy is mainly generated for absorbing the peaks of energy demand, which is basically attended in Spain by conventional thermic and nuclear plants, needing to import some energy from France as well. Sudden flow fluctuations take place below reservoirs used for energy production, with no consideration to the aquatic environment. Since 1981 there is an increase of the construction rate of small hydropower systems, subsidized by the Spanish governement and the EEC, under the erroneous idea of no environmental impact ("clean energy"). This last hydroelectic regulation is specially impacting recondite streams that otherwise would be in pristine conditions.

During the last years, an increase of irrigation land is taking place in Spain, needing to dam more water for this use despite the public opposition in some cases like "Riaiio reservoir". Horticulture and fruit crops are more demmanded in the European Market and most of the traditional agriculture is being abandoned and replaced by irrigation crops.

The installation and maintenance of reservoirs, even if designed primarly for irrigation pourposes, substantially reduce flood peaks in dryland rivers (ALDRIDGE \& EYCHANER, 1984). High dams also cause a shift to the 
right of flood frecuency curves for the downstream areas because floods of a given magnitude are smaller than before the construction of the dam, as was shown for the Duero Basin by MICHEL (1979) (see fig. 1). The large flows released in summer turns over completely the natural regimes of the Iberian mediterranean watersheds.

\section{WATER TRANSFERS}

There are many interbasin water transfers to attend water needs of the big cities (Madrid, Barcelona, Bilbao, Sevilla, etc.), which mainly are provided by superficial runoff.

However, the largest water transfer in Spain is the TajoSegura, which transports water from the upper reach of River Tajo, in a mountaneous area, to the Segura River, in a traditional irrigation area. This water transfer operates since 1978 and transports 100 to 350 millions of cubic meters of water per year, according to the disponibilities in the origin. Some biological effects have been reported in the Segura Basin, like the introduction of the gudgeon (Gobio gobio, L.) and golden carp (Carassius auratus L.) not existing before (MAS-HERNANDEZ, 1986).

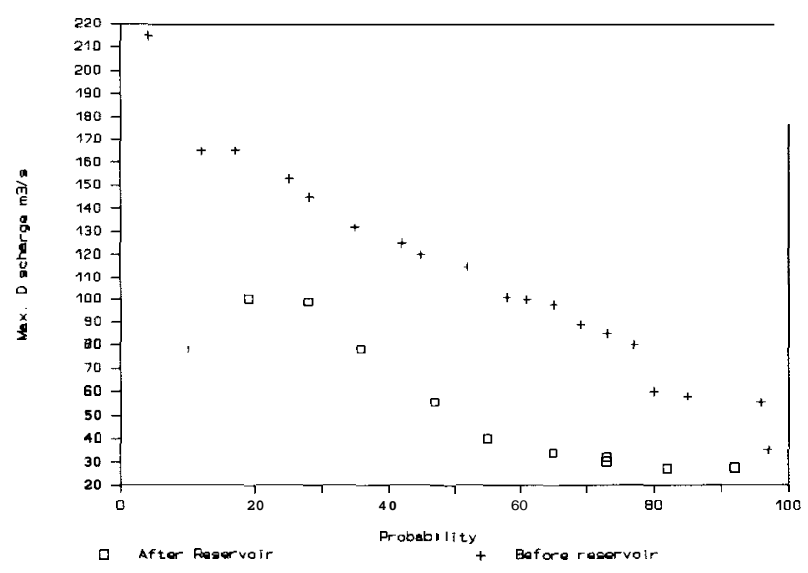

Figure I. Frequency of annual floods for the river Duero at Peñafiel comparing before reservoir regulation (1931-45) and after regulation (1950-60) (after MICHEL, 1979).

\section{THE LIMNOLOGICAL EFFECTS OF STREAM REGULATION}

Any study dealing with the ecology of running waters in Spain will most often be placed in a regulated reach. Despite of the intensive stream regulation that has been undertaken in this country, little attention has been paid to its effects on lotic ecosystems. Previous reviews of the few studies on Spanish regulated streams and some general effects of regulation on lotic communities were presented by GARCIA de JALON (1984, 1987).

Fishes.

Sea migration fishes are of course the most affected organisms. Most of the Iberian large rivers have big dams located in their lower reaches, that have caused the disappearance of some species above them, like mullets, shads, lampreys, eels, and sturgeon (ELVIRA et al. 1991, in press).

This is specially dramatic in the case of the eel, that used to be the only autoctonous fish-predator in all medium and low elevation streams in the Center of Spain (GARCIA de JALON \& LOPEZ-ALVAREZ, 1983) and now is restricted to the coastal areas of the Iberian peninsula (DOADRIO et al., 1991). Today, the eel has nearly disappeared, being replaced by introduced species such as lucio, black-bass, or sun-fish.

Other migration species also very affected by dams are the salmon and seatrout, present in the Northern coast. In this case the impact is mainly produced by small hydropower stations which weirs cut the way up to the spawning sites, lacking most of the stations of effective scales. Figure 2 shows how salmon captures have declined along different years, reaching close at a probable extinction.

Irrigation reservoirs, generally sited in the piedemont of mountain ranges, have different effects on trout fisheries according to their location.

Upstream these reservoirs trout populations have been affected by the increase of cyprinids, specially barbels (Barbus spp.), boga and loina (Chondrostoma spp.), which are well adapted to the lentic conditions of the reservoir's tails and margins. Spring upstream spawning migrations of these cyprinids invade trout reaches (BARCELO \& GARCIA de JALON 1986, RODRIGUEZ et $a l ., 1991)$ and displace trout populations to head streams, disrupting the territorial behaviour of the last ones (CASADO et al., 1989).

Inmediately downstream of these reservoirs there is a decrease of trout populations caused by extremely low temperatures, strong flows and some times low oxygen content. However, in some rivers, trout fisheries seems to be favoured some distance below the dam, by the cold water released from the bottom outlets for summer irrigation. This cold water has allowed the trout to invade lower reaches that would otherwise be unappropriate for them, specially because of not having enough dissolved oxygen limited by the temperature. 


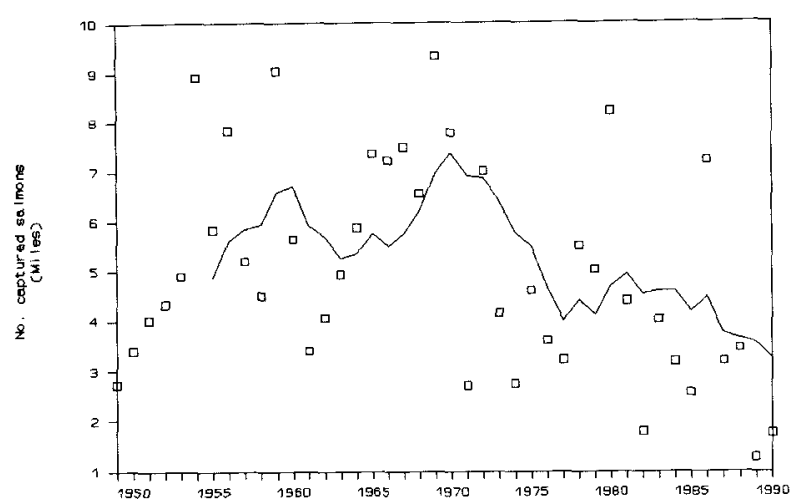

Figure 2. Evolution and tendency of salmon captures in Spain (thousands) during the last 40 years.

\section{Macroinvertebrates.}

In Spain, as in all temperate rivers, stream regulation affects in general macroinvertebrate communities by the reduction of their faunal richness, the alteration of their taxonomic composition and population densities (WARD \& GARCIA de JALON (1991). However, chironomids do not follow this general patterns as has been found in River Llobregat bellow La Baells reservoir (PRAT et al., 1983) where this taxocenosis increases the species richness and diversity.

Among the first studies concerning the effects of regulated flows on benthic macroinvertebrates is worthy to comment the work of PRAT (1981), who reports the influence of the Susqueda reservoir on the river Ter (Catalonia). Water discharge and temperature were considered the main factors controlling composition and growth changes in the stone-dwelling organisms. A high discharge between March and July caused a relative increase of the developement of benthic fauna, compared with that produced in the same period but in other years with minimal discharge. Low water temperatures have affected the life cycle of Psychomyia pusilla (Trichoptera), reducing its growth and limiting the two yearly generations to one. Also, low temperatures have caused a poor developement of the alga Cladophora and the species associated with it, such as Hydroptila (Trichoptera) and certain Chironomidae (Diptera).

GARCIA de JALON (1980) has studied the changes in stream benthic communities caused by the Pinilla reservoir in the Lozoya river (Central Spain), which is used for water supply to Madrid city. Comparing upstream and downstream communities, it is shown that benthic communities sited below the dam are exposed to a qualitative (reduction of total number of species and diversity, and modification of trophic structure) and quantitative (decrease of total density) degradation. Natural recovery takes place slowly; six kilometres downstream, the community parameters increase but do not reach the values attained above the reservoir, and the trophic structure maintains the dominance of collectors.

\section{Aquatic communities.}

The effects of hydroelectric reservoirs in the downstream communities of different Spanish stream types are perhaps the better studied. In River Cinca, a high altitude Pyrenean stream, GARCIA de JALON et al. (1988) evaluated the effects of a high head, low water capacity hydropower system. The macrobenthic fauna of the regulated Cinca was compared with the unregulated River Ara. Colder summer water temperatures in R. Cinca are shown to cause a reduction in community species richness as a consequence of the elimination of thermophilous species. Reduced temperatures may also explain the lower growth rate and productivity of the trout populations. Likewise, sudden flow fluctuations caused by hydropower generation influenced the macrobenthic communities as their populations were less abundant (reduction in densities and biomass and their structure less diverse). Although trout fisheries did not seem to be directly affected by sudden flow fluctuations, the limitation of their food resources (macrobenthos) reduced trout production and turnover ratio.

The limnological impacts of an hydropeaking regulation in a castillean chalk stream, River Duraton, was studied by CAMARGO \& GARCIA de JALON (1990). This river is regulated by Burgomillodo Reservoir, a $40 \mathrm{~m}$. depth, eutrophic reservoir solely used for hydropower. The regulated flow pattern of hypolimnial releases is characterized by daytime flows higher than' those at night, with low flows at weekends.

The effects dowstream this reservoir were assessed by comparing physicochemical characteristics of water and aquatic communities of an upstream site, with those of three downstream stations at $0.2,2.5$, and $7.6 \mathrm{~km}$ below the dam. Water temperature, $\mathrm{pH}$ and dissolved oxygen were significantly lower downstream from the reservoir. Hardness, alkalinity, suspended inorganic matter and conductivity had reduced annual variability below the dam. Photosynthetic activity was directly involved in the recovery of dissolved oxygen and $\mathrm{pH}$ values. Species richness and abundance of macrophytes increased just below the dam. Macroinvertebrates and fish communities were composed of higher 
numbers of potamic species. Number of taxa, density, biomass and diversity were higher at the reference site, recovering their values as the distance below the reservoir increased. Macrobenthic trophic structure was changed by an increase of predators and filter feeders and a decrease of shredders.

From all involved parameters, it was concluded that the main factors from Burgomillodo reservoir affecting the macrobenthos in Duraton river were oxygen deficit and short-term flow fluctuation, meanwhile fish fauna was altered by the oxygen deficit.

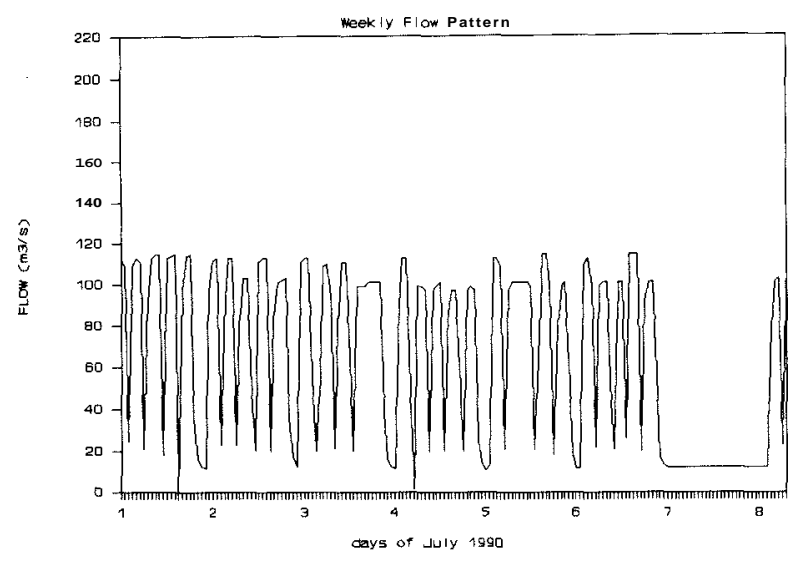

Figure 3a. Hydroelectric flow regime below Valparaiso reservoir in summer: 5 dayly fluctuations during working days and larger base flow on weekends.

Regarding the impacts of hydropower generation on large rivers, MUÑOZ \& PRAT (1989) and PRAT et al. (1988) have studied the last $50 \mathrm{~km}$ of the river Ebro. The changes induced in flow regime have resulted on changes in water quality, transforming the last $20 \mathrm{~km}$ of the river into a estuarine-like system with saline intrusion. Effects of regulation seem to be important in supplying very high nutrient content for algae, causing a high biomass and production especially in summer. Among the primary productors, diatoms and Chlorophyta were the most abundant groups (phosphorus was higher than $5 \mu \mathrm{mol} \mathbf{1}^{-1}$ ). These high biomass also explains the presence of abundant filter-feeders, such as Hydropsyche spp. and Ephoron virgo. In some parts, where light reaches the bottom, stones and boulders were covered by Cladophora. In this case, saline tolerant grazers such as the gastropods Melanopsis and Theodoxus were abundant.

However, most of Spanish reservoirs have a multiple use, and their effects on lotic communities are more difficult to be predicted. This is the case of the Cernadilla and the Valparaiso reservoirs on river Tera (NW Spain) used for irrigation and hydropower generation, which impacts have been reported by CASADO et al. (1989) and GARCIA de JALON \& SANCHEZ-FERNANDEZ (in press).

The overall effects of these reservoirs on downstream communities can be generalized as seasonal and adverse, reducing macrophytes, faunistic richness (both fishes and macroinvertebrates), and fish biomass, density and growth. During spring, macrobenthic density and biomass increased below reservoirs due to the fact that beneficials effects of eliminating damaging floods were greater than the adverse effects caused by short-term flow fluctuations. In contrast, during summer the biomass and densities of downstream communities were reduced. In this case, although daily flow fluctuations have shorter amplitude ( 1.5 to $\left.15 \mathrm{~m}^{3} / \mathrm{s}\right)$ than the winter-spring ones (fig. 3 ), their effects outweight the benefits of cooler water and eliminating extreme low flows. The recovery of the lotic communities $24 \mathrm{~km}$ downstream the dam was only qualitative for the macrobenthos (spp. richness and diversity), while neither macrophytes nor fisheries achieve their upstream values.

The interaction between the effects produced on river Ter by the pollution above a system of three reservoirs (Sau, Susqueda and El Pastoral) and the ecological discontinuities caused by the reservoirs themselves were reported by PUIG et al. (1987) and SABATER et al. (1989, 1991). This interaction resulted in effects that balanced one another, as more than $81 \%$ of the nutrients entering the reservoir was retained. The answer of the biological communities to this interaction differs from diatoms to macroinvertebrates. Diatoms respond mainly to water chemistry and so they do not reflect any discontinuity from reaches above pollution and below

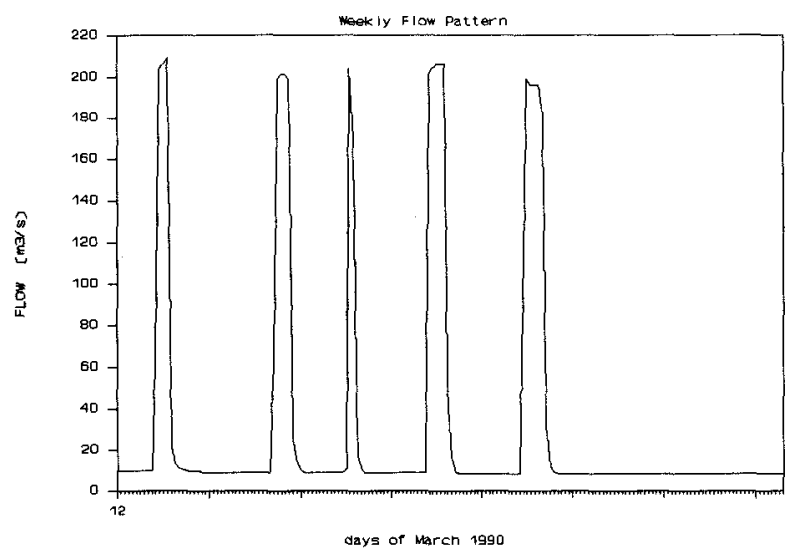

Figure 3b. Winter flow pattern with one large dayly fluctuation during working days and lower base flow on weekwnds (after GARCIA DE JALON \& SANCHEZ, in press). 
the reservoirs. While in the macroinvertebrate community. remarkable shifts in composition occur as a consequence of the disruption in the physical conditions of the river, although the community diversity did not changed.

\section{CONCLUSIONS}

Flow regulation in Spain has been one of the priorities to social development during the last decades, attending to solve intensive irregularities of water resources distribution, both in terms of time and space. Today, there are more than a thousand big dams constructed, and more than 92 large reservoirs under construction or projected to increase the actual storage water capacity of $45,000 \mathrm{Hm}^{3}$ to $60,000 \mathrm{Hm}^{3}$.

As a consequence, the ecology of rivers and streams has been deeply altered, although little attention is still been paid to study the regulation effects. Even less attention have been given to compensation or minimum flows released below reservoirs, that never have been evaluated from an ecological basis (GARCIA de JALON, 1990).

Migration fishes have been the most affected. Anguilla anguilla has disappeared from central reaches where it used to be very abundant, and salmon (Salmo salar) and seatrout (Salmo trutta trutta) populations have declined to nearly extinction in many Cantabric streams.

Macroinvertebrate communities have been also affected by dams in their composition and structure, decreasing in most of the cases their species richness. Sudden flow fluctuations from hydropower reservoirs, as well as lower water temperature, have been reported as the main factors impacting these communities, although the multiple use of the majority of Spanish reservoirs makes rather complex the assessment of their effects on aquatic fauna.

\section{REFERENCES}

ALDRIGE, B.N. y J.H. EYCHANER. 1984. Floods of October 1977 in southern Arizona and March 1978 in New Mexico, and adjacent basins in Arizona. U.S. Geol. Surv. Wat. Supply Pap. 1850-C.

BARCELO, E. \& D. GARCIA DE JALON. 1986. Edad y crecimiento de la boga de rio (Chondrostoma polylepis Steind., 1865) en la Cuenca del Duero. Limnetica 2: 235-240.

CAMARGO, J.A. y D. GARCIA DE JALON. 1991. The downstream impacts of the Burgomillodo reservoir, Spain. Regul. Rivers: Res. \& Mgt. 5, 305-17.
CASADO, C., D. GARCIA DE JALON, C. MONTES, E. BARCELO \& F. MENES. 1989. The effect of an irrigation and hydroelectric reservoir on its downstream communities. Regulated Rivers. Research and Management 4: 275-284.

DGOH (Dirección General de Obras Hidraulicas). 1986. Inventario de Presas Españolas 1986. Publ. MOPU, Madrid.

DOADRIO, I., B. ELVIRA y Y. BERNAT (eds.). 1991. Peces continentales españoles. Inventario y clasificación de zonas fluviales. Col. Técnica. Publ. ICONA, Madrid.

ELVIRA, B., A. ALMODOVAR y J. LOBON-CERVIA 1991. Recorded distribution of sturgeon (Acipenser sturio L.) in the Iberian Peninsula and actual status in spanish waters. Arch. Hydrobiol. 121(2), 253-258.

ELVIRA, B., I. DOADRIO, J. LOBON-CRVIA \& A. SOSTOA (in press). Red list of the freshwater fishes of Spain. Procs. 6th Cong. Europ. Icthiol. Budapest.

GARCIA DE JALON, D. 1984. Stream Regulation in Spain. En: Regulated Rivers. A. Lillehammer \& S.J. Saltveit (eds.), 481-494. Universitets forlaget, Univ. Oslo.

GARCIA DE JALON, D. 1987. River Regulation in Spain. Regulated Rivers. Research and Management 4(1): 343-348.

GARCIA DE JALON, D. 1990. Técnicas hidrobiologicas para la fijación de caudales ecologicos mínimos. En: Libro homenaje al Profesor D. M. García de Viedmu. 183-196. A. Ramos, A. Notario \& R. Baragaño (eds.). FUCOVASA. UPM. Madrid.

GARCIA DE JALON, D. \& J.V. LOPEZ ALVAREZ. 1983. Contribución al conocimiento de la distribución geografica y mesológica de las principales especies piscícolas de la Cuenca del Duero en el verano de 1981. Actas I Congreso español de Limnología: 214-226, Barcelona.

GARCIA DE JALON, D., C. MONTES, E. BARCELO, C. CASADO \& F. MENES. 1988. Effects of a Hydroelectric Regulation on Fluvial Ecosystems from the Spanish Pyrenees. Regulated Rivers. Research and Management 4(2): 479-492.

GARCIA de JALON, D. \& P. SANCHEZ-FERNANDEZ ( in press). Evaluation of downstream effects caused by a new reservoir comparing the fluvial communities before and after its construction. Procs. Fith Int. Symp. Regul. Streams. Montana.

MAS HERNANDEZ, J. 1986. La ictiofauna continental de la Cuenca del rio Segura. Evolución historica y estado actual. Anls. Biol. Pub. Univ. Murcia (Biol. Amb. 2) 8, 3-17.

MICHEL, M. 1979. The effect of reservoir implementation on the discharge of the River Duero in Central Spain. BS Diss, Dep. Geogr. King's College, London. 
MUNOZ, I. \& N. PRAT. 1989. Effects of river regulation on the Lower Ebro river (NE Spain). Reg. Rivers: Res. \& Mngt. 3, 345-254.

PUIG, M.A., J. ARMENGOL, G. GONZALEZ, J. PENUELAS, S. SABATER \& F. SABATER. 1987. Chemical and biological changes in the Ter river induced by a series of reservoirs. In: Regulated Streams: Advances in Ecology. J.F. Craig \& J.B. Kemper (eds.). Plenum Press. New York.

PRAT, N., M.A. PUIG, G. GONZALEZ \& X. MILLET 1983. Chironomid Longitudinal Distribution and Macroinvertebrate Diversity along the Llobregat River (NE Spain). Mem. Amer. Ent. Soc. 34, 267-278.

PRAT, N., I. MUÑOZ, J. CAMP, F.A. COMIN, J.R. LUCENA, J. ROMERO \& M. VIDAL. 1988. Seasonal changes in particulate organic carbon and nitrogen in the river and drainage channels of the Ebro Delta (NE Spain). Verh. Internat. Verein. Limnol. 23, 1344-1349.

SABATER, F., J. ARMENGOL \& S. SABATER. 1989. Measuring discontinuites in the Ter river. Reg. Rivers: Res. \& Mngt. 3, 133-142.

SABATER, S., J. ARMENGOL, E. MARTI, F. SABATER \& H. GUASCH. 1991. Benthic diatom communities as descriptors of discontinuities in the river Ter, Spain. In: B.A. Whitton \& R.E. Friedrich (eds.). Use of algae for monitoring of river-S. 157-163. Univ. Insbrick.

WARD, J.V. \& D. GARCIA de JALON. 1991. Ephemeroptera of regulated mountain streams in Spain and Colorado. 567-578. In: J. Alba-Tercedor \& A. Sanchez-Ortega (eds.). Overview and Strategies of Ephemeroptera and Plecoptera 